\title{
Pulmonary effects of exposures in silicon carbide manufacturing
}

\author{
J M PETERS, ' T J SMITH, ${ }^{2}$ L BERNSTEIN,' W E WRIGHT, ' AND S K HAMMOND ${ }^{2}$ \\ From the Occupational Health Division, ${ }^{1}$ Department of Family and Preventive Medicine, University of \\ Southern California School of Medicine and the Occupational Health Program, ${ }^{2}$ Harvard School of Public \\ Health, Boston, Mass 02115, USA
}

\begin{abstract}
Chest $x$ rays, smoking histories, and pulmonary function tests were obtained for 171 men employed in the manufacturing of silicon carbide. A lifetime exposure to respirable particulates (organic and inorganic fractions) and sulphur dioxide was estimated for each worker. Chest $x$ ray abnormalities were related to respirable particulates (round opacities) and to age and smoking (linear opacities). Pulmonary function was affected by respirable particulates (FVC) and by sulphur dioxide and smoking $\left(\mathrm{FEV}_{1}\right)$. Pleural thickening was related to age. No exposures exceeded the relevant standards; we therefore conclude that the current standards do not provide protection against injurious pulmonary effects, at least in this industry.
\end{abstract}

Production of silicon carbide entails exposures to common air borne contaminants that are present throughout heavy industry. The manufacturing process consists of running an electric current through graphite that lies in a mixture of sand, coke, and sawdust. Operating the furnaces and handling the feedstock, product, and spent mixture exposes workers to sulphur dioxide and respirable particulates containing organics, crystalline silica, and silicon carbide ( $\mathrm{SiC}$ ) (a common abrasive). These processes are thoroughly described in a companion paper. ${ }^{1}$

Sulphur dioxide $\left(\mathrm{SO}_{2}\right)$ has been shown to cause transient acute effects on pulmonary function in people briefly exposed to $1 \mathrm{ppm}$ to $5 \mathrm{ppm}$ in laboratory studies. ${ }^{2-4}$ Long term exposures to $\mathrm{SO}_{2}$ have been associated with non-specific pulmonary disease, but these studies have failed adequately to define the levels of chronic exposure..$^{5-8}$

A study of copper smelter workers showed increased respiratory symptoms and excessive loss of pulmonary function associated with $1.0 \mathrm{ppm}$ to $2.5 \mathrm{ppm} \mathrm{SO} \mathrm{S}_{2}$ exposure after controlling for smoking and exposure to particulates.9 Although two other recent studies of copper smelter workers did not show an effect on pulmonary function from longterm exposure to similar levels of $\mathrm{SO}_{2}$, these studies did not measure exposures to $\mathrm{SO}_{2}$ but used job

Revised 21 October 1982

Accepted 6 December 1982 categories as indicators of different levels of exposure. ${ }^{1011}$ The use of protective masks by workers has been shown to reduce exposures in all job categories to approximately the same levels, ${ }^{12}$ which may explain why other investigations did not find an effect.

There has been much interest in possible synergistic interaction between $\mathrm{SO}_{2}$ and particulates. The combined effect has proved to be difficult to evaluate, however, and there is still controversy about the occurrence of a synergistic effect of $\mathrm{SO}_{2}$ and particulates in man. ${ }^{13}$

The hydrocarbon emissions in the $\mathrm{SiC}$ process are similar to those in the coke oven process. Several studies have shown an association between chronic bronchitis and exposure to coke oven emissions. ${ }^{14}$ is For silicon carbide workers, further work is needed to determine what part, if any, the particulate hydrocarbon and other organic materials may play in the development of chronic lung disease.

The hazards of exposure to crystalline silica are widely recognised. ${ }^{16}$ Workers who mine coal and metallic ores, and who work in foundries manufacturing stone, clay, and glass products and abrasives are exposed to various forms of silica. A series of studies of pulmonary function in Vermont granite workers provided evidence that a low level of exposure to quartz dust $\left(100 \mu \mathrm{g} / \mathrm{m}^{3}\right)$ was associated with abnormal lung function..$^{17-20}$ Recently, the validity of these results has been challenged, ${ }^{21}$ and a re-evaluation of those data is under way. 
Synthetic abrasives are widely used in modern industry, and $\mathrm{SiC}$ is one of the most common. A review of published results concerning health effects of $\mathrm{SiC}$ indicates few studies relevant to the evaluation of long term health effects of this material. Two synthetic abrasive manufacturing plants have been studied, one in some detail..$^{22-25}$ In both cases there were findings of excessive silicosis and chest $x$ ray changes. In both of these plants there was concurrent exposure to aluminium oxide. There has been only one study of workers exposed to emissions from $\mathrm{SiC}$ production ${ }^{26}$ in which early radiographic changes and mild symptoms were found, as well as a pronounced loss in vital capacity over a six year period in some workers.

Thus even though reports are scanty and the effects are confounded by concurrent exposures to aluminum oxide and other materials, there is evidence that $\mathrm{SiC}$ may cause pneumoconiosis. This potential problem has not been fully evaluated.

This study was conducted to determine the pulmonary effects of exposure to $\mathrm{SO}_{2}, \mathrm{SiC}$, quartz, and organic particulates separately and in combination.

\section{Methods}

\section{STUDY POPULATION}

Of the approximately 200 individuals employed in the manufacture of $\mathrm{SiC}$ at the time of this survey in 1979 , exposure assessment, satisfactory chest radiographs, pulmonary function data, and smoking histories were available for 171 .

\section{EXPOSURE EVALUATIONS}

The details of the techniques used to obtain estimates of exposures to air contaminants are presented elsewhere ${ }^{1}$ and are only briefly summarised here.

Personal exposures to sulphur dioxide $\left(\mathrm{SO}_{2}\right)$ and total respirable particulate were measured for the 21 job categories and five work areas. About half the samples for respirable particulate were analysed for total inorganic matter and crystalline silica content. Quartz was the only form of crystalline silica present in significant concentrations. The other half of the samples were extracted with methylene chloride to measure total extractable organic matter.

Exposure to $\mathrm{SO}_{2}$, respirable particulate, quartz, inorganic matter, and extractable organic matter for each job were estimated by the geometric mean of all individual exposures measured for workers in that job. In some cases multiple samples were col-lected for the same individual; these were averaged to estimate the individual's exposure. Although the duration of daily exposures varied from two to eight hours, all daily exposures were time-weighted to eight hours. We assumed that no exposure occurred when the worker was away from the work site.

Occupational histories were obtained from the company records for each subject. These contained the sequence and duration of jobs held by each individual since he started work at the company. In some cases there were gaps where the individual had served in the armed forces, and a few had worked for other companies for brief periods.

The occupational histories were used in combination with the exposures for the jobs to calculate cumulative exposures for each of the air contaminants. The cumulative exposure of a given worker was calculated by multiplying the exposure for each job by the duration in that job and summing over all jobs in the history. Cumulative exposure was selected as the dose index because it is proportional to the total amount of air contaminant deposited in the lungs.

\section{PULMONARY FUNCTION TESTS}

Forced vital capacity (FVC) and forced expiratory volume in one second $\left(\mathrm{FEV}_{1}\right)$ were measured by the pulmonary unit in the Centre Hospitalier Regional de la Mauricie on a preprogrammed computerised spirometer. The maximum value was taken from three satisfactory tracings with the subject standing and using nose clips. Values were adjusted for BTPS. The prediction equations of Knudson et $a^{27}$ were used to calculate expected values for FVC and $\mathrm{FEV}_{1}$.

\section{CHEST RADIOGRAPHS}

Standard 72 inch posteroanterior chest radiographs were taken. The radiographs were classified according to the ILO International Classification of Radiographs of Pneumoconioses (1980 edition) by three NIOSH certified " $B$ " readers. They were read independently and without knowledge of exposure, age, or other information. Categories of profusion (from $0 / 0$ to $3 / 3$ ) read by the three readers were ranked sequentially from 0 to 9 and each subject's readings were averaged to estimate his "true" level of profusion. Shape of opacities was determined by majority; if two readers noted " $p$ " opacities and one " $s$ " then the opacities were called round. Pleural thickening was considered to be present if it was identified by any reader.

\section{SMOKING HISTORIES}

Information on smoking status, present cigarette consumption for smokers, and years since last smoked for ex-smokers was ascertained by interview for the individuals in the study. Smoking categories were defined as non-smoker, ex-smoker, and current low ( $<15$ cigarettes/day), medium (15-25 
cigarettes/day), and high ( $>25$ cigarettes/day) consumption. For tabular presentation, smoking status has been dichotomised into "never smoked" and "ever smoked."

\section{STATISTICAL ANALYSIS}

Multiple regression techniques were used to analyse the relationship between the given percentage predicted pulmonary function measure (FVC and FEV $_{1}$ ) and cumulative exposure to respirable particulates (and its components, quartz, inorganic particulates, and extractable hydrocarbons) and $\mathrm{SO}_{2}$ controlling for smoking habits. Analysis of variance (ANOVA) was performed to evaluate the relation between the exposure and pulmonary function and shape of opacities. These procedures were implemented using the SPSS batch system for the DEC PDP-11.28 Multiple logistic regression models were fitted to assess the effects of cumulative exposure on the presence or absence of profusion, linear opacities, round opacities, and pleural thickening using the general linear interactive modelling system (GLIM) distributed by the Royal Statistical Society. ${ }^{29}$

\section{Results}

\section{EXPOSURE}

A summary of relevant information on exposure appears in table 1 . The range of concentration of the airborne materials is presented with our estimates of the mean cumulative exposure for the cohort. Average exposures are all below the existing standards for permissible exposure.

The respirable particulate fraction was composed of inorganic and organic components. The inorganic particulate fraction is further broken down by determining quartz concentrations. Inorganic matter (mostly SiC) accounts for about half the respirable particulate whereas quartz accounts for about one tenth the inorganic fraction. Only traces of cristobalite and no tridymite were found.

\section{RADIOGRAPHIC FINDINGS}

When opacities were defined as an average profu-
Table 2 Frequency of radiographic abnormalities by shape of opacities and profusion

\begin{tabular}{llll}
\hline Average profusion & \multicolumn{3}{l}{ Shape of opacities } \\
\cline { 2 - 4 } & $\begin{array}{lll}\text { Round } \\
\text { No }(\%)\end{array}$ & Linear & Notal \\
& - & No $(\%)$ \\
\hline None & $20(12)$ & $\overline{21}(12)$ & $70(41)$ \\
$\leqslant 0 / 1$ & $22(13)$ & $14(8)$ & $36(21)$ \\
$>0 / 1$ to $1 / 0$ & $10(6)$ & $14(8)$ & $24(14)$ \\
$\geqslant 1 / 1$ & $52(30)$ & $49(29)$ & $171(100)$ \\
\hline
\end{tabular}

Table 3 Number of workers with opacities* on chest radiograph by age and smoking category

\begin{tabular}{|c|c|c|c|c|c|}
\hline \multirow{2}{*}{$\begin{array}{l}\text { Age } \\
<25 \\
25-34 \\
35-44 \\
45-54 \\
55-64 \\
\text { All }\end{array}$} & \multicolumn{2}{|c|}{ Never-smokers (\%) } & \multicolumn{2}{|c|}{ Ever-smokers (\%) } & Total (\%) \\
\hline & $\begin{array}{l}0 / 7 \\
0 / 13 \\
0 / 5 \\
7 / 8 \\
1 / 5 \\
8 / 38\end{array}$ & $\begin{array}{l}(0) \\
(0) \\
(0) \\
\left(\begin{array}{l}88) \\
20) \\
(21)\end{array}\right.\end{array}$ & $\begin{array}{l}0 / 9 \\
9 / 52 \\
9 / 20 \\
17 / 27 \\
17 / 25 \\
52 / 133\end{array}$ & 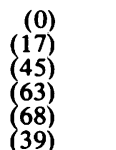 & $\begin{array}{rr}0 / 16 & (0) \\
9 / 65 & (14) \\
9 / 25 & (36) \\
24 / 35 & (69) \\
18 / 30 & (60) \\
60 / 171 & (35)\end{array}$ \\
\hline
\end{tabular}

${ }^{*}$ Defined as an average profusion of greater than $0 / 1$.

Table 4 Opacities on chest radiograph* by cumulative exposure to respirable particulates and smoking category

\begin{tabular}{|c|c|c|c|c|c|}
\hline $\begin{array}{l}\text { Respirable } \\
\text { particulates } \\
\left(\mathrm{mg} / \mathrm{m}^{3} \times \text { year }\right)\end{array}$ & $\begin{array}{l}\text { Never } \\
(\%)\end{array}$ & nokers & $\begin{array}{l}\text { Ever-sn } \\
(\%)\end{array}$ & okers & Total (\%) \\
\hline $\begin{array}{l}0-3 \cdot 6 \\
3 \cdot 7-7 \cdot 4 \\
7 \cdot 5-14 \cdot 9 \\
\geqslant 15 \\
\text { Total }\end{array}$ & $\begin{array}{l}0 / 14 \\
1 / 11 \\
2 / 7 \\
5 / 6 \\
8 / 38\end{array}$ & $\begin{array}{l}(0) \\
(9) \\
(29) \\
83) \\
(21)\end{array}$ & $\begin{array}{l}6 / 37 \\
10 / 32 \\
17 / 38 \\
19 / 26 \\
52 / 133\end{array}$ & $\begin{array}{l}(16) \\
(31) \\
45) \\
73) \\
39)\end{array}$ & $\begin{array}{r}6 / 51 \\
11 / 43 \\
19 / 45 \\
24 / 32 \\
60 / 171\end{array} \quad\left(\begin{array}{l}12) \\
26) \\
42) \\
75) \\
35)\end{array}\right.$ \\
\hline
\end{tabular}

${ }^{*}$ Average profusion greater than $0 / 1$.

sion of greater than $0 / 1,35 \%$ of the 171 workers had some evidence of opacities (table 2). Twenty four $(14 \%)$ of the workers had average profusion readings $1 / 1$ or greater. The group with opacities is classified by smoking habits and age in table 3 . Opacities appear about two decades earlier in eversmokers than never-smokers (table 3 ). Lifetime exposure to respirable particulates is closely related to frequency of opacities for both smokers and non-

Table 1 Characteristics of air contaminant exposures

\begin{tabular}{|c|c|c|c|c|}
\hline \multirow[t]{2}{*}{ Air contaminant } & \multirow{2}{*}{$\begin{array}{l}\text { Current exposures } \\
\text { Range of measured exposure }\end{array}$} & \multicolumn{3}{|c|}{ Estimated cumulative exposures (year)* } \\
\hline & & Mean & $S D$ & Range \\
\hline $\begin{array}{l}\text { Sulphur dioxide }(\mathrm{ppm}) \\
\text { Respirable particulate }\left(\mathrm{mg} / \mathrm{m}^{3}\right) \\
\text { Organic matter }\left(\mathrm{mg} / \mathrm{m}^{3}\right) \\
\text { Inorganic matter }\left(\mathrm{mg} / \mathrm{m}^{3}\right) \\
\text { Quartz }\left(\mathrm{mg} / \mathrm{m}^{3}\right)\end{array}$ & $\begin{array}{l}0 \cdot 0-1 \cdot 5 \\
0 \cdot 1-1 \cdot 5 \\
0 \cdot 0-0 \cdot 2 \\
0 \cdot 1-0 \cdot 6 \\
0 \cdot 0-0 \cdot 1\end{array}$ & $\begin{array}{l}2 \cdot 12 \\
8 \cdot 69 \\
0 \cdot 70 \\
4 \cdot 10 \\
0 \cdot 46\end{array}$ & $\begin{array}{l}3 \cdot 15 \\
7 \cdot 36 \\
0 \cdot 99 \\
3 \cdot 45 \\
0.40\end{array}$ & $\begin{array}{l}0 \cdot 0-18 \cdot 8 \\
0.30-36 \cdot 7 \\
0.01-6.3 \\
0.25-19 \cdot 4 \\
0 \cdot 01-2 \cdot 2\end{array}$ \\
\hline
\end{tabular}

${ }^{*}$ Cumulative exposures were all normalised to eight hours of exposure during a work shift. 
Table 5 Average respirable particulate exposure $\left(\mathrm{mg} / \mathrm{m}^{3} \times\right.$ years) $v$ profusion and shape

\begin{tabular}{llll}
\hline Profusion & Round $(\mathrm{No})$ & Irregular $(\mathrm{No})$ & Both $(\mathrm{No})$ \\
\hline None & - & - & $46 \cdot 2(70)$ \\
$\leqslant 0 / 1$ & $45 \cdot 2(20)$ & $62 \cdot 7(21)$ & $54 \cdot 2(41)$ \\
$>0 / 1$ to $1 / 0$ & $81.6(22)$ & $91 \cdot 1(14)$ & $85 \cdot 7(36)$ \\
$\geqslant 1 / 1$ & $174.3(10)$ & $114.2(14)$ & $139 \cdot 3(24)$ \\
All & & & $69 \cdot 5(171)$ \\
\hline
\end{tabular}

Table 6 Effect of smoking on pulmonary function

\begin{tabular}{|c|c|c|c|c|}
\hline & $\begin{array}{l}\text { Never-smokers } \\
\% \text { Predicted } \\
(n=38)\end{array}$ & $\begin{array}{l}\text { Ever-smokers } \\
\% \text { Predicted } \\
(n=133)\end{array}$ & $\begin{array}{l}\text { ANOVA } \\
p \text {-value }\end{array}$ & $\begin{array}{l}\text { All workers } \\
\% \text { Predicted } \\
(n=171)\end{array}$ \\
\hline $\begin{array}{l}\text { FVC } \\
\text { FEV }_{1}\end{array}$ & $\begin{array}{l}99.3 \\
98.0\end{array}$ & $\begin{array}{l}94 \cdot 7 \\
88 \cdot 8\end{array}$ & $\begin{array}{l}0.04 \\
0 \cdot 002\end{array}$ & $\begin{array}{l}95 \cdot 7 \\
90 \cdot 8\end{array}$ \\
\hline
\end{tabular}

ANOVA $=$ Analysis of variance.

smokers (table 4). In general, smokers show a higher frequency of opacities than non-smokers, although at high cumulative exposures the nonsmokers have similar frequencies. Average lifetime exposure to respirable particulates bore a strong association with profusion category, especially for round opacities (table 5). The relationships between the other exposure variables and opacities are much less striking.

\section{PULMONARY FUNCTION TESTS}

To adjust for difference in age and height the pulmonary function values are presented as a percentage of the predicted based on the prediction equations of Knudson et al.$^{27}$ Our workers averaged 39.7 years of age with $14 \cdot 1$ years of employment. The average pulmonary function values as a percentage of predicted were $95.7 \%$ for FVC and 90.8 for FEV $_{1}$ (table 6). The differences between neversmokers and ever-smokers are significant for both FVC $(p=0.04)$ and FEV, $(p=0.002)$.

Levels of pulmonary function related to exposure are presented in table 7 . Cumulative exposure to respirable particulates has a strong effect on both FVC and $\mathrm{FEV}_{1}$ in ever-smokers. In never-smokers these differences are not statistically significant, although there is a downward trend for $F E V_{1}$ similar to that in ever-smokers. Cumulative $\mathrm{SO}_{2}$ exposure is related to level of $\mathrm{FEV}_{1}$ in ever-smokers but not FVC. Duration of employment bears a significant relation to both FVC and FEV 1 in ever-smokers but not in never-smokers (table 8).

\section{PULMONARY FUNCTION RELATED TO}

RADIOGRAPHIC CHANGES

Table 9 contains the data on pulmonary function broken down by smoking and radiographic profu-

Table 7 Percentage predicted pulmonary function and cumulative respirable particulate and $\mathrm{SO}_{2}$ exposure by smoking

\begin{tabular}{|c|c|c|c|c|}
\hline \multirow{2}{*}{$\begin{array}{l}\text { Respirable particulates } \\
\left(m g / m^{3} \times y r\right)\end{array}$} & \multicolumn{2}{|l|}{ Ever-smokers } & \multicolumn{2}{|l|}{ Never-smokers } \\
\hline & $\%$ Predicted FVC (No) & $\%$ Predicted FEV & $\%$ Predicted FVC (No) & $\%$ Predicted FEV \\
\hline $\begin{array}{l}0-3 \cdot 6 \\
3 \cdot 7-7 \cdot 4 \\
7 \cdot 5-14.9 \\
\geqslant 15 \\
\text { ANOVA p-value }\end{array}$ & $\begin{array}{l}98.7 \%(37) \\
95.6 \%(32) \\
94.9 \%(38) \\
87.8 \%(26) \\
0.009\end{array}$ & $\begin{array}{l}92 \cdot 6 \% \\
91 \cdot 8 \% \\
88 \cdot 2 \% \\
80.4 \% \\
0.018\end{array}$ & $\begin{array}{ll}101 \cdot 7 \% & (14) \\
98 \cdot 2 \% & (11) \\
98.4 \% & (7) \\
96 \cdot 8 \% & (6) \\
\text { NS } & \end{array}$ & $\begin{array}{l}103 \cdot 2 \% \\
97 \cdot 4 \% \\
93 \cdot 1 \% \\
92 \cdot 9 \cdot \% \\
\text { NS }\end{array}$ \\
\hline $\begin{array}{l}\mathrm{SO}_{2}(\mathrm{ppm} \times \text { year }) \\
0-0.37 \\
0.38-0.74 \\
0.75-2.2 \\
\geqslant 2.2 \\
\text { ANOVA p-value }\end{array}$ & $\begin{array}{l}96.8 \%(37) \\
97.4 \%(29) \\
94.7 \%(30) \\
90.5 \%(37) \\
0.103\end{array}$ & $\begin{array}{l}92.4 \% \\
92.2 \% \\
89.6 \% \\
81.7 \% \\
0.018\end{array}$ & $\begin{aligned} 100.2 \% & (14) \\
94.3 \% & (4) \\
99.2 \% & (9) \\
100 \cdot 0 \% & (11) \\
\text { NS } & \end{aligned}$ & $\begin{array}{l}101 \cdot 3 \% \\
92 \cdot 3 \% \\
95 \cdot 2 \% \\
98 \cdot 2 \% \\
\text { NS }\end{array}$ \\
\hline
\end{tabular}

ANOVA $=$ Analysis of variance.

Table 8 Duration of employment and percentage predicted pulmonary function by smoking

\begin{tabular}{|c|c|c|c|c|c|c|}
\hline \multirow[t]{2}{*}{ Duration } & \multicolumn{3}{|c|}{ Ever-smokers } & \multicolumn{3}{|c|}{ Never-smokers } \\
\hline & $F V C$ & $(N o)$ & $F E V_{1}$ & $F V C$ & $(N o)$ & $F E V_{1}$ \\
\hline $\begin{array}{l}<5 \\
5-9 \\
10-14 \\
15-19 \\
20-24 \\
25-29 \\
30-34 \\
35-39 \\
\text { ANOVA p-value }\end{array}$ & $\begin{array}{r}100 \% \\
96 \% \\
100 \% \\
88 \% \\
92 \% \\
97 \% \\
91 \% \\
82 \% \\
0.001\end{array}$ & $\begin{array}{l}(24) \\
(45) \\
18) \\
(11) \\
(6) \\
(7) \\
\left(\begin{array}{l}10) \\
12\end{array}\right)\end{array}$ & $\begin{array}{l}95 \% \\
91 \% \\
96 \% \\
83 \% \\
78 \% \\
90 \% \\
80 \% \\
76 \% \\
0.003\end{array}$ & $\begin{array}{l}97 \% \\
101 \% \\
100 \% \\
105 \% \\
104 \% \\
97 \% \\
95 \% \\
97 \% \\
\text { NS }\end{array}$ & $\left.\begin{array}{r}(11) \\
(10) \\
(4) \\
(5) \\
1 \\
2) \\
4 \\
1\end{array}\right)$ & $\begin{array}{r}97 \% \\
100 \% \\
97 \% \\
107 \% \\
109 \% \\
78 \% \\
93 \% \\
96 \%\end{array}$ \\
\hline
\end{tabular}

ANOVA $=$ Analysis of variance. 
Table 9 Percentage predicted pulmonary function by profusion of opacities and smoking

\begin{tabular}{|c|c|c|c|c|c|c|}
\hline \multirow{2}{*}{$\begin{array}{l}\text { Profusion } \\
\text { category }\end{array}$} & \multicolumn{2}{|l|}{$A l l$} & \multicolumn{2}{|l|}{ Ever-smokers } & \multicolumn{2}{|c|}{ Never-smokers } \\
\hline & $\begin{array}{l}\% \text { Predicted } \\
\text { FVC (No) }\end{array}$ & $\begin{array}{l}\text { \% Predicted } \\
F E V_{1}\end{array}$ & $\begin{array}{l}\text { \% Predicted } \\
\text { FVC (No) }\end{array}$ & $\begin{array}{l}\text { \% Predicted } \\
F E V_{1}\end{array}$ & $\begin{array}{l}\text { \% Predicted } \\
\text { FVC (No) }\end{array}$ & $\begin{array}{l}\text { \% Predicted } \\
F E V_{1}\end{array}$ \\
\hline $\begin{array}{l}\text { None } \\
\leqslant 0 / 1 \\
>0 / 1-1 / 0 \\
\geqslant 1 / 1 \\
\text { ANOVA p-value }\end{array}$ & $\begin{array}{l}97.4 \%(70) \\
97.6 \%(41) \\
94.0 \%(36) \\
90.3 \%(24) \\
0.06\end{array}$ & $\begin{array}{l}94.8 \% \\
91 \cdot 1 \% \\
89.5 \% \\
80.8 \% \\
0.004\end{array}$ & $\begin{array}{l}96.3 \%(48) \\
97.5 \%(33) \\
92.7 \%(29) \\
90.1 \%(23) \\
0.11\end{array}$ & $\begin{array}{l}92.4 \% \\
90.5 \% \\
87.7 \% \\
80.0 \% \\
0.02\end{array}$ & $\begin{array}{ll}99.8 \% & (22) \\
98.2 \% & (8) \\
99.3 \% & (7) \\
96.9 \% & (1) \\
\text { NS } & \end{array}$ & $\begin{array}{l}100 \cdot 0 \% \\
93 \cdot 4 \% \\
97 \cdot 2 \% \\
98 \cdot 0 \% \\
\text { NS }\end{array}$ \\
\hline
\end{tabular}

ANOVA $=$ Analysis of variance.

Table 10 Pulmonary function by shape of opacity and smoking $(n=171)$

\begin{tabular}{|c|c|c|c|}
\hline Shape & $A l l(N o)$ & Ever-smokers (No) & Never-smokers (No) \\
\hline $\begin{array}{l}\text { None } \\
\text { Round } \\
\text { Linear } \\
\text { ANOVA p-values }\end{array}$ & $\begin{array}{l}97 \cdot 4\left(\begin{array}{l}70) \\
95 \cdot 3 \\
93.9 \\
\text { NS }\end{array}\right) \\
\text { NS }\end{array}$ & $\begin{array}{c}\text { Percentage predicted FVC } \\
96 \cdot 3(48) \\
94 \cdot 1 \quad 42) \\
93 \cdot 6(43) \\
\text { NS }\end{array}$ & $\begin{aligned} 99.8 & (22) \\
100.4 & (10) \\
95.6 & (6) \\
\text { NS } & \end{aligned}$ \\
\hline $\begin{array}{l}\text { None } \\
\text { Round } \\
\text { Linear } \\
\text { ANOVA p-value }\end{array}$ & $\begin{array}{l}94 \cdot 8(70) \\
91 \cdot 7 \\
84 \cdot 3 \\
0.002\end{array}\left(\begin{array}{l}52 \\
49)\end{array}\right.$ & $\begin{array}{c}\text { Percentage predicted FEV } \\
92.4(48) \\
90.2 \\
83.4(42) \\
0.025\end{array}$ & $\begin{array}{c}100 \cdot 0 \\
98 \cdot 1 \\
90 \cdot 8 \\
\mathrm{NS}\end{array}$ \\
\hline
\end{tabular}

ANOVA $=$ Analysis of variance.

Table 11 Pulmonary function by presence of pleural thickening

\begin{tabular}{lllr}
\hline $\begin{array}{l}\text { Pleural } \\
\text { thickening }\end{array}$ & $\begin{array}{l}\text { \% Predicted } \\
\text { FEV }\end{array}$ & $\begin{array}{l}\text { \% Predicted } \\
\text { FVC }\end{array}$ & No \\
\hline $\begin{array}{l}\text { Absent } \\
\text { Present }\end{array}$ & $92.0 \%$ & $96.8 \%$ & 149 \\
$\begin{array}{l}\text { ANOVA } \\
\text { p-value }\end{array}$ & $\mathbf{8 2 . 6 \%}$ & $\mathbf{8 8 . 8 \%}$ & 22 \\
\hline
\end{tabular}

ANOVA $=$ Analysis of variance.

sion. Level of $F E V_{1}$ as a percentage of predicted is significantly related to profusion category for the whole group and for ever-smokers but not for never-smokers. The relationship between profusion category and FVC is of borderline significance ( $p=$ 0.06 ) for the entire group.

The group of individuals with linear opacities has lower values for both FVC and FEV, irrespective of smoking habits although statistical significance is reached only for $\mathrm{FEV}_{1}$ (table 10).

Pleural thickening is present in 22 individuals. In 16 this is associated with linear opacities, in three with round, and in three with no opacities. Pleural thickening is associated with significantly lower values for both FVC and FEV (table 11).

\section{EFFECTS OF CONFOUNDING}

Since many of the independent variables in the present study are interrelated (age, exposure duration, years smoked, lifetime exposure to $\mathrm{SO}_{2}$, particulates) multiple regression and logistic regression were used to determine the major independent effects. The summary of these analyses is presented in table 12. For profusion, age and respirable particulates were the significant variables. Cumulative exposure to respirable particulates was the only

Table 12 Significant independent variables identified by multiple linear regression or logistic regression

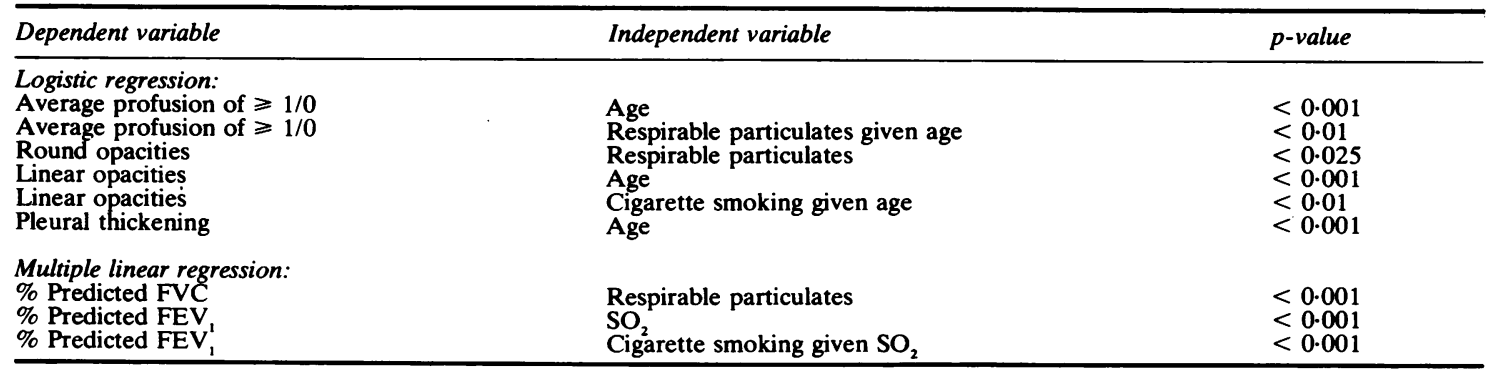


significant variable for round opacities, whereas age accounted for linear opacities with smoking habit based on consumption also being significant. Cumulative exposure to respirable particulates was related to low FVC whereas cumulative exposure to $\mathrm{SO}_{2}$ was associated with low FEV . Smoking was also related to loss of $\mathrm{FEV}_{1}$ but not as strongly associated as $\mathrm{SO}_{2}$. Age was significantly related to pleural thickening and smoking habit was of borderline importance.

\section{Discussion}

The results clearly show that this population has been affected by exposures at work. Some relations between exposure and effect appear to be clear, others less clear.

\section{RESPIRABLE PARTICULATES}

Respirable particulates are clearly related to the profusion of opacities, to the round shape of opacities, and to the reduction in FVC. Smoking appears to enhance these effects, although the small number of never-smokers may raise some doubt about this. When we attempted to look at the effects of subfractions of respirable particulates (quartz, and other inorganics), the correlation between these exposure variables was so high that the effects of the subfractions could not be differentiated (respirable particulates $v$ quartz, $\mathrm{r}=0.90$; respirable particulates $v$ other organics, $\mathrm{r}=0.91$; quartz $v$ other organics, $r=0.87$ ). From this study we therefore cannot conclude which component(s) of the respirable particulates is primarily responsible for the effects.

If quartz is the "active" ingredient in respirable particulates then effects on chest radiographs and FVC are seen at levels considerably below the current permissible exposure. The highest exposure to quartz was $0.1 \mathrm{mg} / \mathrm{m}^{3}$ in the present study.

Although not measured directly, $\mathrm{SiC}$ represents the largest fraction of the inorganic portion of the respirable particulates. $\mathrm{SiC}$ is considered a nuisance dust although there is some evidence that it may cause lung disease. ${ }^{25} 26 \mathrm{If} \mathrm{SiC}$ is the "active" agent in the respirable particulate then the observed effects are seen at levels far below currently permissible exposure levels. The highest average exposure to $\mathrm{SiC}$ in this study was $0.57 \mathrm{mg} / \mathrm{m}^{3}$, although individual exposures could have been higher.

\section{SULPHUR DIOXIDE}

Sulphur dioxide had the most significant effect on $\mathrm{FEV}_{1}$. The effect of smoking was also significant. $\mathrm{SO}_{2}$ exposures are less tied to respirable particulates $(r=0.74)$, therefore it is possible to separate the effects in this study. The levels of $\mathrm{SO}_{2}$ in this working environment are well below the current permissible standards. The effect of $\mathrm{SO}_{2}$ on $\mathrm{FEV}_{1}$ in this study is seen at levels of exposure below $1.5 \mathrm{ppm}$. Acute effects ${ }^{2-4}$ have been seen at this level, and one previous study showed chronic effects at approximately this level. ${ }^{9}$ We 'found no interaction between $\mathrm{SO}_{2}$ and respirable particulate exposure.

\section{SMOKING}

Cigarette smoking had the expected effect on FEV . Smoking also affected the age at which opacities appear and was highly significant in explaining linear opacities $(\mathrm{p}<0.01)$.

\section{INTERACTIONS}

The fact that age, duration of exposure, years of smoking, and cumulative exposure to the different dusts and gases are so highly correlated makes it difficult to identify single effects. It is even more difficult to look at interactions. The issue of particulate $/ \mathrm{SO}_{2}$ interaction has been of interest for many years. We see no interaction in our study with $\mathrm{SO}_{2}$ primarily affecting the $\mathrm{FEV}_{1}$, and respirable particulate the FVC and chest $x$ ray. The former finding is consistent with a study of smelter workers. ${ }^{9}$ Smoking enhances the roentgenographic changes associated with dust and also adds to the effect of SO, on FEV, as expected.

Whether the combination of quartz, SiC, and organic component acts synergistically cannot be determined in the present study. The clear excess of radiographic abnormalities and pulmonary function impairment associated with exposures that singly are not excessive may suggest this possibility. Another possibility is that one or more of the standards for permissible exposure are set at levels that do not protect exposed workers. Prospective studies in this industry involving refined and detailed air sampling along with repeated measurements of pulmonary function and radiographs over time should help resolve this question.

We acknowledge the support and cooperation of $\mathrm{Dr}$ Rene Tremblay of the Departmente de Sante Communautaire (DSC) Centre Hospitalier Regional de la Mauricie, Quebec, and the help of P Rasmussen in the preparation of the manuscript.

Requests for reprints to: Dr John M Peters, University of Southern California School of Medicine, 2025 Zonal Avenue, Los Angeles, California 90033. 


\section{References}

' Smith TJ, Hammond SK, Laidlaw F, Fine S. Respiratory exposures associated with silicon carbide production: estimation of cumulative exposures for epidemiological study. $\mathrm{Br} \mathrm{J}$ Ind Med 1984;41: $100-8$.

${ }^{2}$ Anderson I, Lundquist GR, Jensen PL, Proctor DF. Human response to controlled levels of sulphur dioxide. Arch Environ Health 1974;28:31-9.

${ }^{3}$ McJilton C, Frank R, Charlson R. Role of relative humidity in the synergistic effect of sulphur dioxide-aerosol mixture on the lung. Science 1973;182:503-4.

${ }^{4}$ Lawther PJ, Macfarlane AJ, Waller RE, Brooks AGF. Pulmonary function and sulphur dioxide, some preliminary findings. Environ Res 1975;10:355-67.

${ }^{5}$ Kehoe RA, Machle WF, Kitzmiller K, LeBlanc TJ. On the effects of prolonged exposure to sulphur dioxide. $J$ Ind Hyg 1932;14:159-73.

- Anderson A. Possible long term effects of exposure to sulphur dioxide. Br J Ind Med 1950;7:82-6.

' Skalpe IO. Long-term effects of sulphur dioxide exposure in pulp mills. Br J Ind Med 1964;21:69-73.

${ }^{8}$ Ferris BG, Burgess WA, Worcester J. Prevalence of chronic respiratory disease in a pulp mill and a paper mill in the United States. Br J Ind Med 1967;24:26-37.

${ }^{9}$ Smith TJ, Peters JM, Reading JC, Castle CH. Pulmonary impairment from chronic exposure to sulphur dioxide in a smelter. Am Rev Respir Dis 1977;116:31-9.

${ }^{10}$ Lebowitz MD, Burton A, Kaltenborn W. Pulmonary function in smelter workers. JOM 1979;21:255-9.

" Federspiel CF, Layne JT, Auer C, Bruce J. Lung function among employees of a copper mine smelter: lack of effect of chronic sulphur dioxide exposure. JOM 1980;22:438-44.

${ }^{12}$ Smith TJ, Wagner WL, Moore DE. Chronic sulphur dioxide exposure in a smelter I. Exposure to $\mathrm{SO}_{2}$ and dust: $1970-4$. JOM 1978;20:83-7.

${ }^{13}$ Committee on Sulfur Oxides, Board on Toxicology and Environmental Health Hazards, Assembly of Life Sciences, National Research Council. Sulfur oxides. Washington: National Academy of Sciences, 1978:180-96.

${ }^{14}$ Walker DD, Archibald RM, Attfield MD. Bronchitis in men employed in the coke industry. Br J Ind Med 1971;28:358-63.

is Mittman C, Pedersen E, Barbela T. Prediction and potential prevention of industrial bronchitis: an epidemiologic study of a group of coke oven workers. Am J Med 1974;57:192-9.

${ }^{10}$ Hunter D. The pneumoconioses. In: Diseases of occupations. Boston: Little, Brown \& Co, 1955:848-54.

17 Theriault GP, Burgess WA, DiBerardinis LJ, Peters JM. Dust exposure in the Vermont granite sheds. Arch Environ Health 1974;28:12-7.

${ }^{18}$ Theriault GP, Peters JM, Fine LJ. Pulmonary function in granite shed workers of Vermont. Arch Environ Health 1974;28:1822.

19 Theriault GP, Peters JM, Johnson WM. Pulmonary function and roentgenographic changes in granite dust exposure. Arch Environ Health 1974;28:23-7.

${ }^{20}$ Musk AW, Peters JM, Wegman DH, Fine LJ. Pulmonary function in granite dust exposure: a four year follow-up. Am Rev Respir Dis 1977;115:769-76.

${ }^{21}$ Graham WGB, O'Grady RV, Dubuc B. Pulmonary function loss in Vermont granite workers: a long-term follow-up and critical reappraisal. Am Rev Respir Dis 1981;123:25-8.

${ }^{22}$ Clark WI. The dust hazard in the abrasive industry: second study. J Ind Hyg 1929;11:92-6.

${ }^{23}$ Clark WI, Simmons EB. The dust hazard in the abrasive industry. J Ind Hyg 1925;7:345-51.

${ }^{24}$ Wegman DH, Eisen E. Causes of death among employees of a synthetic abrasive product manufacturing company. JOM 1981;23:748-54.

${ }^{25}$ Smith AR, Perina AE. Pneumoconiosis from synthetic abrasive materials. Occupational Medicine 1948;5:396-402.

${ }^{26}$ Bruusgaard A. Pneumoconiosis in silicon carbide workers. Proceedings of the Ninth International Congress on Industrial Medicine. London: 1948:13-7.

${ }^{27}$ Knudson RJ, Slatin RC, Lebowitz MD, Burrows B. The maximal expiratory flow-volume curve. Am Rev Respir Dis 1976;113:587-600.

${ }^{28} \mathrm{Nie}$ NH, Hull CH. SPSS 11. Preliminary manual. Chicago: Statistical Package for the Social Sciences, Inc, 1980.

${ }^{29}$ Nelder JA. GLIM Manual, Release 2. General linear interactive modelling. Oxford: Numerical Algorithms Group, 1975. 